\title{
МЕТОДИ ВИХОВАННЯ ДИТИНИ В РОДИНІ В УКРАЇНСЬКИХ НАРОДНИХ КАЗКАХ
}

\author{
Плотнікова В. I. \\ аспірантка III курсу кафедри педагогіки \\ Криворізький державний педагогічний університет \\ пр. Гагаріна, 54, Кривий Ріг, Дніпропетровська область, Украӥна \\ orcid.org/0000-0003-0948-2993 \\ asp-18-plotnikova@kdpu.edu.ua
}

\author{
Ключові слова: сімейне \\ виховання, батьки, діти, \\ родинна педагогіка, народна \\ педагогіка, етнопедагогіка.
}

Наші пращури з великою пошаною ставилися до родинних стосунків, зображуючи виховний вплив сім’ї на їі членів. Особливо це стосується українських народних казок, у сюжетах яких відображено методи виховання дитини. Батько та мати присутні у розповіді, навіть якщо вони не згадуватимуться у подальших подіях, адже народ високо поціновував їхній вплив на формування дитини. Визначено, що зазначені методи відрізнялися відповідно до життєвого досвіду вихованців. Кожен персонаж стикається 3 переломним моментом на різних проміжках існування, тому виділяти періоди залежно від віку вважаємо недоречним. Виокремлено такі етапи життя героїв в українських народних казках: підготовчий, випробувальний та констатувальний. На підготовчому етапі дитина зазвичай перебуває в межах рідної оселі, села, краю та набуває знань, умінь та навичок, необхідних для повноцінної реалізації у світі. У вихованні батьки можуть використовувати такі методи, як: повчання, метод прикладу, привчання, доручення та інші. Випробувальний етап пов'язаний з перевіркою здобутих знань, умінь та навичок за умови самостійного існування поза межами батьківської домівки, села, краю. На зазначеному проміжку часу батьки послуговуються такими методами виховання, як: настанови, вимоги, доручення, змагання, заохочення тощо. Доручення чи вимога батьків набувають особливої ваги, адже часто саме 3 них починається випробування героя. Констатувальний етап демонструє результат соціалізації персонажа, який може як повернутися до батьків, так і створити власну родину у новому середовищі. До методів виховання, використовуваних батьками, зараховано нагороду чи покарання. Не всі персонажі українських народних казок заслуговують на щасливий фінал, деякі 3 них опиняються у тяжкому становищі чи навіть помирають. Таке завершення свідчить про серйозне ставлення народу до правильного виховання дітей у родині та усвідомлення можливих наслідків помилок батьків. Для успішної реалізації методи на різних етапах повинні бути взаємопов’ язані, системні, послідовні та свідомі. Перераховані методи виховання застосовуються у родині задля повноцінного щасливого існування дитини у майбутньому. 


\title{
METHODS OF CHILD'S UPBRINGING IN THE FAMILY IN UKRAINIAN FOLK TALES
}

\author{
Plotnikova V. I. \\ Postgraduate Student of the 3rd year at the Department of Pedagogy \\ Kryvyi Rih State Pedagogical University \\ Gagarin ave., 54, Kryvyi Rih, Dnipropetrovsk region, Ukraine \\ orcid.org/0000-0003-0948-2993 \\ asp-18-plotnikova@kdpu.edu.ua
}

Key words: upbringing, parents, children, family pedagogy, folk pedagogy, ethnopedagogics.

\begin{abstract}
Our ancestors had great respect for family relationships, depicting the upbringing impact of the family on its members. This is especially true for Ukrainian folk tales, the plots of which show methods of child's upbringing. The father and mother are mentioned in the plot, even if they do not influence the development of events in the future, because the people highly appreciated their influence on the formation of the child. It was determined that these methods differed according to the life experience of the pupils. Each character faces a turning point in different periods of existence, so we consider it inappropriate to distinguish periods depending on age. The following stages of the heroes' lives in Ukrainian folk tales are singled out: preparatory, testing and ascertaining. At the preparatory stage, the child usually stays within its own home, village, region and acquires the knowledge, skills and abilities necessary for the full realization in the world. The parents can use the following methods in the upbringing: teaching, example using, training, assigning and others. The testing stage is associated with the verification of acquired knowledge, skills and abilities, provided that one exists independently outside the parental home, village, region. During this time, parents use the following methods of upbringing: guidelines, requirements, instructions, competitions, encouragement, and so on. The instructions or requirements of parents become especially important, because often it is from them that the trial of the hero begins. The ascertaining stage demonstrates the result of the character's socialization, who can both return to his or her parents and create his or her own family in a new environment. The methods of upbringing, which are used by parents, include reward or punishment. Not all characters in Ukrainian folk tales deserve a happy ending; some of them find themselves in a difficult situation or even die. This conclusion shows the serious attitude of the people to the proper upbringing of children in the family and awareness of the possible consequences of parents' mistakes. The methods must be interconnected, systematic, consistent and conscious at different stages for successful implementation. These methods of upbringing are used in the family for the complete happy existence of the child in the future.
\end{abstract}

Постановка проблеми. Звернення до національних здобутків особливо важливе у періоди нестабільності та криз. Перевірні часом надбання народу можуть використовуватися нащадками у поєднанні $з$ новітніми тенденціями. Так, народна педагогіка містить чимало ідей, придатних для реалізації у сучасних реаліях. У цьому контексті слід згадати, що в українських народних казках найгрунтовніше розкрито виховання у сім'ї дітей різного віку. Дослідження методів виховання дитини у родині, представлених в українських народних казках, збагатить етнопедагогічну думку та родинну педагогіку, дасть змогу збагнути причини, якими керувалися персонажі-батьки, визначити досвід пращурів, актуальний і донині.

Родинне виховання у народній педагогіці цікавило не одне покоління дослідників. Першим вважатимемо О. Духновича, який у праці «Народна педагогія» виокремив відповідальність батьків за первинне виховання дітей, методи схвалення, покарання, роль особистого прикладу [1, с. 12]. Грунтовний аналіз родинного виховання здійснив М. Стельмахович. Науковець виокремлює у народній педагогіці батьківську педагогіку як 
передачу дорослими членами сім'ї дитині духовного й виробничого досвіду, прищеплення культури поведінки [2, с. 7]. Серед методів виховання у родині дослідник зазначає такі як: вимога, спонукання [2, с. 29], роз'яснення, бесіда [2, с. 149], прилучання [2, с. 158]. До родинного виховання в народній педагогіці зверталися Т. Алексеєнко, О. Вишневський, О. Івановська, В. Кузь, О. Любар, А. Марушкевич, Н. Побірченко, В. Постовий, Н. Рогальська, Ю. Руденко, Р. Чмелик, П. Щербань та інші. В українській фольклористиці приділено увагу соціальним ролям родини, зображеним у народних казках (О. Бріцина, В. Давидюк, I. Денисюк, В. Сокол).

Взаємодію батьків і дітей в українських народних казках розглядали О. Мазяр та О. Юрчак (відторгнення дитини у сім'ї, навіювання, заборона, гіперопіка). Дослідники виокремили кілька станів дитини та батьків у сюжеті: «Дитина», «Дорослий», «Дитина-Пристосуванець», «Турботливий Родитель», «Родитель-Критик» та інші [3, с. 76]. Методи виховання дитини у родині, представлені в українських народних казках, також не залишилися поза увагою дослідників. Так, Т. Краюшкіна виокремлює поради $[4$, с. 84], покарання [4, с. 87], доручення $[4$, с. 90], наказ [4, с. 91]. У монографії Л. Мушкетик натрапляємо на згадки систематичного виховання дитини батьками в українських народних казках. Особливо поціновувалися доброта, скромність, чемність, пошана до старших [5, с. 98]. Серед методів виховання авторка виділяє поради [5, с. 108], дозвіл [5, с. 109], привчання до праці [5, с. 117]. На думку дослідниці, значний виховний вплив на дитину у казках чинить матір [5, с. 140]. Н. Годзь згадує про вигнання 3 дому (покарання) та поради від батьків [6]. Проте методи виховання у родині дітей на різних етапах життя в українських народних казках ще не висвітлені у науковій літературі.

Мета - дослідити методи родинного виховання дитини на різних етапах життя в українських народних казках.

Виклад основного матеріалу. В «Українському педагогічному словнику» знаходимо визначення методів виховання як «сукупності найбільш загальних способів розв'язання виховних завдань і здійснення виховних взаємодій, способів взаємопов'язаної діяльності вихователів і вихованців, спрямованих на досягнення цілей виховання» [7, с. 206]. Сімейне виховання трактується як «одна 3 форм виховання дітей, що поєднує цілеспрямовані педагогічні дії батьків з повсякденним впливом сімейного побуту» [7, с. 306]. Тому розгляд методів виховання дитини у родині в українських народних казках буде грунтуватися на способах розв'язання виховних завдань та здійснення виховних взаємодій в умовах впливу сімейного побуту задля досягнення цілей виховання.
Відзначимо, що в українських народних казках на різних проміжках життя персонажа характерна перевага одних методів виховання над іншими, проте ми не можемо послуговуватися періодизацією відповідно до шкільного навчання. Вікова періодизація також повністю не відповідає сюжетам казок, адже в них протиріччя настає не 3 досягненням певного віку, а виникає у разі потреби долати труднощі, які індивідуальні для кожного. Тому виокремимо підготовчий, випробувальний та констатувальний етапи життя героїв в українських народних казках.

Підготовчий етап - період життя дитини від народження і до настання випробування. До характерних рис уналежнимо: перебування в межах батьківської домівки чи рідного краю; попереднє ознайомлення 3 навколишнім світом; виконання деяких доручень; можливу наявність закріплених обов'язків; набуття знань, умінь та навичок, необхідних для самостійного життя; відповідальність за дитину несуть батьки чи особи, які їх заміняють (дідусь, бабуся, мачуха, вітчим, тварини-охоронці чи навіть чарівні предмети). Виховуючи дитину, батьки послуговуються різноманітними методами, однак не всі з них мають на меті розв'язати виховні завдання. До методів виховання, що спричиняють появу новоутворень у характері та світогляді дитини на підготовчому етапі, зарахуємо: повчання, метод прикладу, привчання, доручення, бесіду, спонукання. В українських народних казках батьки повчають дітей ще 3 раннього віку. Це можуть бути роз'яснення правил, яких слід дотримуватися, пояснення соціального становища героя чи його родини, прищеплення моральних норм, застереження щодо можливих небезпек. Наприклад, у казці «Про двох королевичів і їхню сестру» мати научає дочок щодо майбутнього заміжжя [8]. Користуються батьки й методом прикладу під час виховання. У родині дитина спостерігає за старшими, вони демонструють їй зразки поведінки, які наслідують молодші члени сім'ї. Зокрема, у казці «Батьківська наука» цар наказав кидати старих людей на поталу хижим звірам. Коли син несе батька до лісу, старий користується власним прикладом, щоб переконати хлопця [9]. Не нехтують в українських народних казках $\mathrm{i}$ методом привчання. Він полягає у залученні до хатньої роботи, вихованні рис характеру та прищепленні норм поведінки, вимогах наслідувати певний ритуал тощо. Так, у казці «Дідова наука» батьки намагаються прищепити синам працьовитість, залучаючи їх до порання по господарству [10]. На підготовчому етапі трапляються й доручення, які має виконати дитина. Зазвичай вони не потребують значних зусиль та радше покликані розвивати вміння планувати власну діяльність та нести відповідальність за її наслідки (виконання 
обов'язків по господарству, допомога у сімейних чи громадських справах тощо). Прикладом слугує казка «Царський син і вовк», у якій батько наказує синам стерегти золоту яблуню по черзі [11]. Як бачимо, доручення не складне, проте виховує уважність, сумлінність та кмітливість. Батьки поціновували й бесіду як один 3 незамінних методів виховання. В українських народних казках дитина відчуває себе частиною родини, тож ми натрапляємо на численні розмови між старшим та молодшим поколіннями (запитання щодо проведеного дня, виконаної роботи, успіхів чи невдач, цікавість до оточення дитини). Згадаємо казку «Дванадцять братів», де батьки проводять із синами бесіду щодо усталених традицій (неприпустимість старших поклонятися молодшим) [11]. Варто виокремити й спонукання як заохочення дитини до бажаного вчинку (заохочення до праці, розумової діяльності, самостійного та гідного існування та інших занять, які задаються сім'ї корисними). Так, у казці «Батькове золото» батько, щоб спонукати лінивих дітей до праці, хитрує, говорячи, що на городі приховане золото, але він не згадує, де саме. Шукаючи скарб, хлопці стають працьовитими господарями [12].

Випробувальний етап для героїв українських народних казок необхідний та надзвичайно важливий. Від успішності його подолання залежить подальша доля дитини. До характерних рис етапу зарахуємо: перебування поза межами батьківської домівки, краю або потребу самостійно вирішити нову практичну проблему, розв'язання якої суттєво вплине на подальше життя персонажа; перевірку здобутих знань, умінь та навичок на практиці; оточення переносить на випробуваного права та обов'язки дорослого. На зазначеному проміжку часу батьки послуговуються такими методами виховання: настанови, вимоги, доручення, змагання, заохочення. Настанови відрізняються від повчань підготовчого етапу. Якщо останні були детальним напучанням маленької дитини, то настанови випробувального етапу більш узагальнені, вони виряджають героя у дорогу чи на подолання проблеми. Часто це стисла порада, своєрідне нагадування найголовнішого разом 3 вказівкою виконати доручення. Наприклад, у казці «Батьківська порада» батько алегорично наставляє сина перед дорогою, щоб той «мав у кожному селі хату, на кожен день нові чоботи і щоб щоранку всі люди йому кланялися» [9]. Серед методів виховання в українських народних казках не оминути й вимогу, особливістю якої є неможливість ухилення від бажання, прохання, а то й прямого наказу сім'ї. За змістом вона може виявлятися у різноманітних проявах: неухильне дотримання ритуалу, заборона дії чи бездіяльності, наявність обов'язкової умови для одержання бажаної речі тощо. Зокрема, у казці «Батьків заповіт» батько встановлює умову для одержання спадку: сини повинні читати після його смерті книжки над тілом [9]. Значення доручення батьків як методу виховання надзвичайно вагоме. На відміну від доручень попереднього етапу, які виступали як підготовка чи тренування, від результату виконання одержаних завдань на випробувальному етапі залежить майбутнє щастя дитини. Поширеними дорученнями у сюжетах $\epsilon$ пошук чарівного предмета, нареченої, здобуття матеріальних благ, перемога ворога, зайняття господарськими справами та інше. Так, у казці «Батько і сини» князь відправляе синів у мандрівку за чарівним яблуком, що здатне повернути втрачений зір [9]. 3 дорученням тісно пов'язане змагання. У сюжетах казок часто натрапляємо на ситуацію, за якої нагорода обіцяється тільки тому, хто впорається із завданням. У казці «Батько та три сини» батько обіцяє спадок тому синові, який принесе йому перед смертю найкращий подарунок. Майно одержує наймолодший хлопець, що дарує синівську любов [10]. Варто зазначити, що заохочення в українських народних казках може здатися близьким до змагання, адже герой також одержує нагороду, однак відмінність полягає у суперництві, яке не обов'язкове для заохочення. Батьки стимулюють дітей до навчання, працьовитості, сміливості, самостійності, гідного життя тощо. Як приклад наведемо казку «Ківш лиха», у якій батько заохочує сина одержанням спадку, щоб спонукати хлопця до праці [13].

Констатувальний етап є результатом випробування героя та визначає його майбутнє життя. До характерних рис віднесемо: успішне подолання випробування, здобуття благ або трагічний фінал; повернення до батьківської домівки чи створення власної родини; початок самостійного існування як повноцінного члена суспільства. Найпоширенішими методами, що використовуються батьками на цьому проміжку, $є$ нагорода чи покарання. За успішне проходження випробування родина визнає заслуги героя (передача господарства, царства, інших матеріальних благ, примирення з батьками, здобуття пошани тощо). Зокрема, у казці «Батько та три сини» батько розпоряджається спадком на користь сина, шо приніс найліпший подарунок [10]. Покарання від родини також трапляється у сюжетах, однак зауважимо, що батьки не мають на меті засудити чи принизити дитину за невдачу. Вони карають лише за серйозні проступки, вчинки, несумісні з усталеними нормами та мораллю. Наприклад, у казці «Про жар-птицю та вовка» батько карає старших синів за вбивство молодшого [14, с. 267].

Народ розумів умови, необхідні для успішного застосування методів виховання у родині. У казках 
батьки використовують методи системно, послідовно та свідомо, у зв'язку з життям. Так, у казці «Два сини» батько постійно бере із собою на полювання старшого сина [15], а казка «Царський син і вовк» [11] зображує порядок надання доручень від простих до складних (спочатку сини стережуть яблуню, а потім вирушають у мандрівку). Навпаки, у разі безсистемного виховання дитина не здатна пройти випробувальний етап. Так, у казці «Дідова i бабина дочка» бабина дочка помирає, адже не одержала належного виховання у родині [13]. Свідоме застосування методів виховання також украй важливе. У казках «Батьківська наука» [9], «Батькове золото» [12], «Ківш лиха» [13] у родині чітко розуміють, $з$ якою метою та задля яких результатів використовуються ті чи ті методи. «Казка про соловейка» демонструє іншу ситуацію, за якої батьки не замислюються над вибраними методами, засуджують шлюб доньки зі змієм та вбивають його, що приносить тільки нещастя героїні $[14$, c. 245]. Не менш важливий і зв'язок із життям. Застосовані методи виховання пов'язані зі звичним середовищем, $є$ знайомими та зрозумілими для дитини. Це можуть бути господарські турботи («Дідова наука» [10], Батько та три сини» [10], «Батькове золото» [12]), влаштування дорослого життя («Про двох королевичів і їхню сестру» [8]), обговорення стосунків у власній родині («Дванадцять братів» [11]). Протилежні результати спостерігаємо у разі відірваності методів виховання від реального життя. Наприклад, у казці «Дідова дочка і золота яблунька» мати радить дочці прикинутися сестрою, що зрештою призводить до смерті обох [13]. Зрештою, усі методи виховання використовуються батьками задля подальшого щастя дітей, однак народ попереджав про трагічні наслідки їх неправильного застосування.

Висновки і перспективи подальших розробок. У народній педагогіці, а особливо в укра- їнських народних казках, родинне виховання широко представлене. Численні сюжети демонструють нам методи виховання, що використовувалися в сім'ї на різних проміжках життя дитини. Виокремлено такі етапи життя героїв в українських народних казках: підготовчий, випробувальний та констатувальний. Підготовчий етап характеризується перебуванням у межах батьківської домівки чи рідного краю; ознайомленням 3 навколишнім світом; виконанням дрібних доручень; набуттям умінь та навичок, необхідних для самостійного життя; відповідальністю за дитину батьків чи осіб, що їх заміняють. До методів виховання зазначеного етапу зараховано: повчання, метод прикладу, привчання, доручення, бесіду, спонукання. Для випробувального етапу типовими $\epsilon$ : перебування поза межами батьківської домівки, краю або потреба самостійно вирішити нову практичну проблему, розв'язання якої суттєво вплине на подальше життя персонажа; перевірка здобутих знань, умінь та навичок на практиці; оточення переносить на випробуваного права та обов'язки дорослого. У цей час батьки застосовують такі методи виховання: настанови, вимоги, доручення, змагання, заохочення. Констатувальний етап завершує випробування героя та характеризується поверненням до батьківської домівки чи створенням власної родини; початком самостійного існування як повноцінного члена суспільства. Методи виховання батьків зводяться до нагороди чи покарання. Народна мудрість виокремлює необхідні умови для успішного використання методів виховання у родині (системність, послідовність, свідомість, зв'язок $з$ життям).

У подальшому планується дослідження виховних ролей членів родини, моделей розвитку дитини в українських народних казках, визначення виховного потенціалу українських народних казок.

\section{ЛІТЕРАТУРА}

1. Духнович А.В. Народная педагогия в пользу училищ и учителей сельских. Часть I. Педагогия общая. Львов : типом Института Ставропигиянского, 1857. 92 с. URL: http://books.e-heritage.ru/ book/10083744 (дата звернення: 12.01.2021).

2. Стельмахович М.Г. Українська народна педагогіка. Київ : IЗМН, 1997. 232 с.

3. Мазяр О.В., Юрчак О.С. Життєві сценарії в українських народних казках. Практична психологія та соиіальна робота. 2011. № 2. С. 73-77.

4. Краюшкина Т.В. Мир семейных отношений в русских народных волшебных сказках : монография. Владивосток : Дальнаука, 2005. 204 с.

5. Мушкетик Л.Г. Персонажі української народної казки : монографія. Київ : Український письменник, 2014. $360 \mathrm{c.}$

6. Годзь Н.Б. Культурні стереотипи в українській народній казці : автореф. дис. ... канд. філол. наук : 09.00.04. Харків, 2004. 20 с.

7. Гончаренко С.У. Український педагогічний словник : довідкове видання. Київ : Либідь, 1997. 373 с.

8. Українські народні казки : у 40 книгах. Тернопіль : Богдан, 2005. Казки Покуття / Запис, упорядк. і літ. опрац. М.A. Зінчук. 416 c. URL: https://proridne.org/Фольклор\%20Покуття/ (дата звернення: 12.01.2021). 
9. Українські народні казки : у 40 книгах. Чернівці : Прут, 2010. Казки Полтавщини / Запис, упорядк. i літ. опрац. М.А. Зінчук. 416 c. URL: https://proridne.org/Фольклор\%20Полтавщини/ (дата звернення: 12.01.2021).

10. Українські народні казки : у 40 книгах. Чернівці : Букрек, 2011. Казки Наддніпрянщини / Запис., упоряд. і літ. опрац. М.A. Зінчук. 520 с. URL: https:/proridne.org/Фольклор\%20Наддніпрянщини/ (дата звернення: 12.01.2021).

11. Українські народні казки : у 40 книгах. Львів : Світ, 2003. Казки Гуцульщини / Запис., упорядк. i літ. опрац. М.A. Зінчук. 384 с. URL: https://proridne.org/Фольклор\%20Гуцульщи (дата звернення: 12.01.2021).

12. Українські народні казки : у 40 книгах. Тернопіль : Богдан, 2006. Казки Буковини / Записав, упорядкував і літ. опрацював M.A. Зінчук. 456 c. URL: https://proridne.org/Фольклор\%20Буковини/(дата звернення: 12.01.2021).

13. Українські народні казки : у 40 книгах. Чернівці : ТОВ «Видавництво «Наші книги», 2009. Казки Поділля / Запис., упоряд. і літ. опрац. М.А. Зінчук. 376 с. URL: https://proridne.org/Фольклор\%20 Поділля/ (дата звернення: 12.01.2021).

14. Українські народні казки / за ред. Л.Ф. Дунаєвської. Київ : Веселка, 1991. 367 с.

15. Українські народні казки : у 40 книгах. Чернівці : Букрек, 2011. Казки степової Кіровоградщини / Запис., упоряд. і літ. опрац. М.А. Зінчук. 504 с. URL: https://proridne.org/Українські\%20народні\%20 казки/Два\%20сини.html (дата звернення: 12.01.2021).

\section{REFERENCES}

1. Duhnovich, A.V. (1857). Narodnaya pedagogiya v polzu uchilisch i uchiteley selskih. Chast I. Pedagogiya obschaya [Folk pedagogy in favor of schools and rural teachers. Part I. General education]. Lviv: tipom Instituta Stavropigiyanskogo. Retrieved from: http://books.e-heritage.ru/book/10083744 [in Russian].

2. Stelmakhovych, M.H. (1997). Ukrainska narodna pedahohika [Ukrainian folk pedagogy]. Kiev: IZMN [in Ukrainian].

3. Maziar, O.V., Yurchak, O.S. (2011). Zhyttievi stsenarii v ukrainskykh narodnykh kazkakh [Scenarios of life in Ukrainian folk tales]. Applied psychology and social work. No. 2. Pp. 73-77.

4. Krayushkina, T.V. (2005). Mir semeynyih otnosheniy v russkih narodnyih volshebnyih skazkah [The world of family relations in Russian fairy tales]. Vladivostok: Dalnauka [in Russian].

5. Mushketyk, L.H. (2014). Personazhi ukrainskoi narodnoi kazky [Characters of the Ukrainian folk tale]. Kyiv: Ukrainskyi pysmennyk [in Ukrainian].

6. Hodz, N.B. (2004). Kulturni stereotypy v ukrainskii narodnii kaztsi [The cultural stereotypes in the Ukrainian popular folk fairy tales] (PhD Thesis), Kharkiv, V.N. Karazin Kharkiv National University.

7. Honcharenko, S.U. (1997). Ukrainskyi pedahohichnyi slovnyk [Ukrainian pedagogical dictionary]. Kyiv: Lybid [in Ukrainian].

8. Zinchuk, M.A. (ed.). (2005). Ukrainski narodni kazky. Kazky Pokuttia [Ukrainian folk tales. Tales of Pokutia]. Ternopil: Bohdan. Retrieved from: https:/proridne.org/Folklor\%20Pokuttia/ [in Ukrainian].

9. Zinchuk, M.A. (ed.). (2010). Ukrainski narodni kazky. Kazky Poltavshchyny [Ukrainian folk tales. Tales of Poltava]. Chernivtsi: Prut. Retrieved from: https://proridne.org/Folklor\%20Poltavshchyny/ [in Ukrainian].

10. Zinchuk, M.A. (ed.). (2011). Ukrainski narodni kazky. Kazky Naddniprianshchyny [Ukrainian folk tales. Tales of the Dnieper region]. Chernivtsi: Bukrek. Retrieved from: https://proridne.org/Folklor\%20 Naddniprianshchyny/ [in Ukrainian].

11. Zinchuk, M.A. (ed.). (2003). Ukrainski narodni kazky. Kazky Hutsulshchyny [Ukrainian folk tales. Tales of the Hutsul region]. Lviv: Svit. Retrieved from: https://proridne.org/Folklor\%20Hutsulshchy [in Ukrainian].

12. Zinchuk, M.A. (ed.). (2006). Ukrainski narodni kazky. Kazky Bukovyny [Ukrainian folk tales. Tales of Bukovina]. Ternopil: Bohdan. Retrieved from: https://proridne.org/Folklor\%20Bukovyny/ ([in Ukrainian].

13. Zinchuk M.A.(ed.). (2009). Ukrainskinarodni kazky. Kazky Podillia [Ukrainian folk tales. Tales of Podillya]. Chernivtsi: Nashi knyhy. Retrieved from: https://proridne.org/Folklor\%20Podillia/ [in Ukrainian].

14. Dunaievska, L.F.(ed.). (1991). Ukrainski narodni kazky [Ukrainian folk tales] Kyiv: Veselka [in Ukrainian].

15. Zinchuk, M.A. (ed.). (2011). Ukrainski narodni kazky. Kazky stepovoi Kirovohradshchyny [Ukrainian folk tales. Tales of Kirovograd region]. Chernivtsi: Bukrek, Retrieved from: https://proridne.org/Ukrainski\%20 narodni\%20kazky/Dva\%20syny.htm [in Ukrainian]. 